The Scottish Race and Kingdom

Author(s): James Ferguson

Source: The Celtic Review, Vol. 6, No. 24 (Apr., 1910), pp. 304-334

Published by:

Stable URL: http://www.jstor.org/stable/30070228

Accessed: 06-12-2015 06:59 UTC

Your use of the JSTOR archive indicates your acceptance of the Terms \& Conditions of Use, available at http://www.jstor.org/page/ info/about/policies/terms.jsp

JSTOR is a not-for-profit service that helps scholars, researchers, and students discover, use, and build upon a wide range of content in a trusted digital archive. We use information technology and tools to increase productivity and facilitate new forms of scholarship. For more information about JSTOR, please contact support@jstor.org. 
them with the hair of her head' (St. Luke vii. 38). They follow, however, not the Gender of the Antecedent, but the Sex of the creature signified by the Antecedent, in those words in which Sex and Gender disagree; as, an gobhlangaoithe mar an ceudn' do sholair nead dhi fein, 'The swallow, too, hath provided a nest for herself' (Ps. lxxxiv. 3). Gobhlan-gaoithe, 'swallow,' is a Masc. Noun, as appears by the Masc. Article ; but as it is the dam that is spoken of, the reference is made by the Pers. Pron. to the Fem. Gender. Ta gliocas air a fireanachadh le a cloinn, "Wisdom is justified by her children' (St. Matt. xi. 19). Gliocas is a Masc. Noun, but as Wisdom is here personified as a female, the regimen of the Poss. Pron. is adapted to that idea.'

There seems little doubt but that the sagacious author has hit upon the true explanation of the Gaelic usage in this matter, and that thus we must also explain the invariable use of the Fem. Pronoun to represent such words as mart, ' a cow,' capull, 'a mare,' and boirionnach, 'a female,' 'a woman,' with one or two others which are, grammatically, Masc. Nouns.

\section{THE SCOTTISH RACE AND KINGDOM}

\section{James Ferguson}

I

Two great developments in the history of Scotland are shrouded in mist, and present fascinating subjects for investigation and speculation. One is the process by which, in the long period between King Malcolm Canmore and the union of the Crowns, the Teutonic overshadowed the original Celtic element in the population of the Lowlands from the Forth to the Findhorn, and the Gaelic tongue was superseded by the English speech. The other is the earlier change by which the proper Scots, whose original territory was limited to the county of Argyll, became supreme over 
the larger, more fertile and more populous provinces of the Picts, and imposed their name in the first place on Scotland north of the Forth, and in the second on the territory to the south, as far as the Cheviot range and the Solway shore.

The story of the times, in which the earlier change took place, is told in two different ways. There is the old fabulous history of which the most famous exponents are Boethius and Buchanan, which unhesitatingly deduced the descent of the Scottish Monarch, step by step through a hundred kings, from Fergus I., who lived 330 years before the birth of Christ, and which records a complete extermination of the Picts by Kenneth Macalpin about the year 850 A.D. There is the modern method based on the still older, more matter of fact, and to some extent contemporaneous records of the Irish annalists, the ancient Books of Wales, the Saxon Chronicle of the Northumbrian Bede, and the Norse Sagas, which refuses to accept or to record anything that is not found in these original sources. It has always seemed to me that both these methods are inadequate and, therefore, inaccurate, and that the true spirit in which to write the proper annals of a race or country is to narrate first the actual historical facts established or reasonably proved, and then to add the traditional and legendary history, except where it is disproved or inconsistent with ascertained fact, for what it is worth, stating always the caution of the old genealogist, "This, though it has often been said and may be true, cannot, I believe, be instructed.' Keeping this caution in view, a further distinction falls to be drawn between the earlier mediæval chronicles prior to the War of Independence, on which both Fordun and Wyntoun have based their narratives, and the extended and ornamented achievements of the later historians, with their multiplicity of detail and their moral precedents for their own side of the controversies of their own day.

The old Irish traditions point to at least three different vOL. VI. 
settlements in Ireland. One was a dark race of apparently the same type as the Silures found by the Romans near the Welsh border, and possibly the Basques in Spain, and the Lapps. The second was apparently a Celtic race, and was probably represented by the Pictish population of part of Ulster. The third was the Scots or Sons of Miledh, said to be descended from a Greek who married Scota, the daughter of Pharaoh, and who after being settled in the north of Spain ultimately invaded Ireland. Some of the legends point to a common origin of the Picts and Scots, and deduce both from Gaedhel Glass the son of Scota. A remarkable passage 'from an old book' quoted in the preface to M'Firbis's Book of Genealogies preserves the physical characteristics of the three races :-

' Every one who is white of skin, brown of hair, bold, honourable, daring, prosperous, bountiful in the bestowal of property, wealth and rings, and who is not afraid of battle or combat, they are the descendants of the Sons of Miledh in Erin. Every one who is fair haired, vengeful, large ; and every plunderer ; every musical person; the professor of musical and entertaining performances; who are adepts in all Druidical and magical arts : they are the descendants of the Tuatha de Danaan in Erin. Every one who is black haired, who is a tattler, guileful, tale-telling, noisy, contemptible; every wretched, mean, strolling, unsteady, harsh and inhospitable person; every slave, every mean thief, every churl, every one who loves not to listen to music and entertainment, the disturbers of every council and every assembly, and the promoters of discord among the people, these are the descendants of the Firbolg, the Fir Gailiun of Liogairne and of the Firdomnan in Erin. But however the descendants of the Firbolgs are the most numerous of all these.'

This description points clearly to the sons of Miledh or the Scots as a ruling race of superior physical and moral character, while the characteristics of the Tuatha de Danaan, have striking resemblance to these given by the Roman 
writers of the Caledonian Picts, especially the ruddy hair and huge limbs noted by Tacitus.

Both the legendary and the historic Fergus of seven hundred years later are deduced from the royal race of Ireland. The first distinct historic reference to the Scots is in A.D. 360 when they attacked the Roman province of Britain coming apparently from Ireland. They appear at intervals until the curtain falls with the withdrawal of the Roman legions, and when it rises again the Scots are found established in Scottish Dalriada, the modern Argyll. In the Synchronisms of Flann Mainistrech, compiled in the early part of the eleventh century, it is stated that twenty years after the battle of Ocha in 478 the children of Erc passed over into Alban, and Tighhernac, who died in 1088, writes under the year 501: 'Fergus Mor, son of Erc, held a part of Britain with the tribe of Dalriada (i.e. the Irish Dalriada or north of Ulster) and died there.'

According to the Annals of the Four Masters, Fergus and his brothers 'went into Scotland to assist his maternal grandfather, Loarn, who was King of Dalriada and was much oppressed by his enemies the Picts,' and on his death, ' being of the Blood Royal by his mother,' was chosen to succeed him. It is interesting to note that according to an old Irish source, St. Patrick, to whom Fergus had been liberal in making a grant of land, blessed him and foretold that he should be king and his descendants rule over Alban.

Although this expedition is the foundation of the Scottish Kingdom in Scotland, and Fergus Mor of 500 A.D. was the real ancestor of the Scottish kings, there must have been communication between Ireland and Scotland long before, and there may have been earlier settlements of a less permanent nature which gave rise to the tradition that Fergus restored instead of founded a race and a dynasty. There was, however, a similar relation between the Scottish and Irish Picts. The Ossianic legends and the old Gaelic poems point to a very close connection at an earlier date, and whether Fingal, Diarmid and the other Ossianic 
heroes were Pictish or Scottish Gaels their range in Scotland extended from the western shores of Argyll to at least Strathardle and Glenshee. They were probably Picts of the great Caledonian division. On the other hand some of the Highland Senachies deduced the descent of Fergus Mor from Fergus son of Fingall and brother of Ossian,Fergus Mac Arcaith, Mhic Chomgaill, Mhic Fhearghuis, mhic Fhingaill, nam buath, the Victorious. The Scottish colony of 498 consisted of the Cinel Gabran, which occupied Cowal and Kintyre to the Moss of Crinan, being the descendants of Gabran and Comgall, the two sons of Domangart, son of Fergus; of the Cinel Angus, which settled in Islay and Jura, the descendants of Fergus's brother Angus; and of the Cinel Lorn, descendants of his other brother, Lorn, which occupied the district from the Moss of Crinan to Loch Leven. The names of Comgall and Lorn are preserved in the districts of Cowal and Lorn. The Tract on the Men of Alban of the fourteenth century describes 'the three powerfuls of Dalriada' as consisting of the Cinel Gabran of five hundred and threescore houses, the Cinel Angus of four hundred and thirty houses, and the Cinel Lorn of four hundred and twenty houses, their sea muster being in each case twice seven benches to each twenty houses. It gives the armed muster of the Cinel Gabran as three hundred men, of the Cinel Angus five hundred, and of the Cinel Lorn seven hundred men, adding 'but it is of the Airgialla that the seventh hundred is.' The Airgialla were probably the original inhabitants of the district of Mid-Argyll around Loch Awe, which was practically enveloped by the three tribes, whose capital was the fortified rock of Dunadd in the Moss of Crinan.

Fergus was succeeded by his son Domangart, and he by his son Comgall. Comgall was succeeded by his brother Gabran, who was killed in 560 by Brude Mac-Mailchu, King of the Picts. He was succeeded by Conall, son of Comgall, and on Conall's death, fourteen years later, the succession passed by the law of tanistry to the sons of Gabran, Aidan, 
the younger son, being preferred in consequence of a vision vouchsafed to St. Columba, who solemnly inaugurated him in Iona. The connection between the royal race and the family of Iona was very close. Columba was himself by paternal descent a scion of the parent Irish house of the Hy Niall, his father Feidlimidh being son of Fergus Cennfoda, son of Conall Gulban, one of the eight sons of Niall, of the Nine Hostages, ${ }^{1}$ and being connected in the female line with the kings of Dalriada. According to the old Irish Life of Columba, 'he was eligible to the kingship of Erin, according to family, and it was offered to him if he himself had not abandoned it for God.'

Drostan, the companion of Columba in his mission among the North-Eastern Picts, is described in the Breviary of Aberdeen as of the royal race of the Scots. Leslie says that he was King Aidan's uncle on the mother's side, and Major describes him as uncle on the mother's side of Eochy, son of Aidan. He is also said in the Breviary to have been sent to his uncle St. Columba, in Ireland.

King Aidan attended, along with Columba, the Council at Drumceat in Ireland in 375, when the Scottish Dalriads were freed from all tribute and exactions, but undertook

1 While no definite conclusions can be drawn as to the ancestry of Fergus Mor, son of Erc, except that he was undoubtedly of the Royal race of the Scots in Ireland, it should be noted that three pedigrees are given. One ( $O^{\prime} H a r t ' s$, Irish Pedigrees, Annals of the Frour Masters) is the Irish one which makes him the great-grandson of Niall of the Nine Hostages, and describes him as son of Muredach, son of Eoghanan, son of Niall of the Nine Hostages, one hundred and thirty-first monarch of Ireland (378-405), son of Eochy Muigmedon, the one hundred and twenty-sixth monarch. The second is the early mediæval pedigree, given with slight variations in the Tract on the Men of Alban, the Latin chronicles prior to 1300, recited according to Major by the Highland Senachie at the coronation of Alexander III., and also given by Fordun, which describes him as son of Erc or Erth, son of Eochy Muinremair. The third is the embellished and extended production of misty and fabulous monarchs, with alternating good and bad records, of Boece, Buchanan, and the later historians prior to the critical essay of Innes. The second class of pedigrees deduce the descent through thirty-three descents to Fergus, son of Ferchar, the traditional founder of the Scottish monarchy, which includes the names of two Irish monarchs, Conair and Edirsceol. The earliest Latin chronicle of 1165 says, 'Fergus filius Erc ipse fuit primus qui de semine Chonar suscepit regnum Alban id est a Monte Drum-Alban usque ad mare Hibernie et ad Inchegal.' 
to join the parent stock in all hostings and expeditions. He seems to have largely extended the Dalriadic kingdom. He drove the Saxons out of Manaan, the country in the south-east of Stirlingshire, and, in a battle against the Picts between the Forth and Tay, he was victorious, aided, it is said, by the prayers of Columba in Iona, though four of his sons fell. He was, however, defeated, at the head of a combined force of Scots and Britons, by the Saxons under Aedilfrid, at Degsastan in Liddesdale, in 603. On his death in 606, he was succeeded by his son Eocha Buidhe, or the Yellow-haired, whom Columba had named as his successor. A beautiful tradition tells that on King Aidan presenting his three eldest sons to Columba, and asking which should succeed him, the saint sadly told him that all three would fall in battle, and asked for the younger children to be sent for. When they came in, a fair-haired boy ran forward and flung himself into the arms of Columba, who foretold that he would be the future king.

Eochaidh Buidhe seems to have transferred the throne of Scottish Dalriada to his son Conadh Cerr, and as his death is recorded as King of the Picts in 629, when he was fighting in Ireland in aid of the Irish Picts, Mr. Skene thinks that he had somehow acquired the sovereignty of the Picts of Galloway. Conadh Cerr was succeeded in the same year by his brother Domnall Breac, who was twice defeated by the Angles between the Roman wall and Edinburgh. Hitherto the two Christian nations, the Scots and Britons of Strathclyde, had been in alliance, but Domnall Breac, who had incurred the curse pronounced by Columba on any descendant of Aidan who should ' act unjustly against me and my kin,' and in spite of the obligation as to hostings and expeditions, had sided with the Irish Picts against the Scottish king of Ireland, was slain by King Oan of Strathclyde, in the upper part of the Carron valley in 642 . It would appear that the Britons then established a domination over the Scots, who fell with them under the sway 
of the Angles of Northumbria, being, as Adamnan says, 'trodden down by strangers.'

In 678 the Scots seem to have risen, under Fearchar Fada of the tribe of Lorn, and the defeat of the Saxons by the Picts at Dunnichen in 685 resulted in the Scots and a part of the Britons regaining their liberty. Two lines of descent are now recorded, that in the Cinel Gabran, consisting, after Domnall Breac, of his brother, Conall Crandomna and his two sons, Mailduin and Domnall Donn, who died in 696, and was succeeded by Eocha, grandson of Domnall Breac, who was slain in the following year. Ferchar Fada was in 697 succeeded by his son Ainbhcellaig, and he by his brother Sealbach, whose seat was at Dunolly, and who fought both against the Cinel Gabran and the Britons. In 723 Sealbach became a cleric, and was succeeded by his son Dungal. He was, however, driven out by Eochaidh, son of the Eochaidh, grandson of Domnall Breac, in 726, while Eochaidh's brother Alpin, whose name shows he had a Pictish mother, established himself on the Pictish throne. A more powerful champion existed among the four claimants to the Pictish throne, and Alpin was defeated at Moncreiff by Angus MacFergus, and subsequently by Nectan at Caislen Credi or Scone. Angus ultimately vanquished all his competitors, and the death of Eochaidh having led to an uprising of the family of Lorn, and Dungal, who again seized the throne, having taken captive Angus's son in Ireland, Angus MacFergus, the greatest of all the Pictish kings, invaded Dalriada, took Dunadd, and so completely overwhelmed the race that the tribe of Lorn made a desperate attempt upon the district on the south of the Forth, where they were defeated, while Alpin, who, at the head of the Cinel Gabran, reigned four years after Dungal was thrown into chains by Angus, invaded Galloway with the part of the Dalriadic nation which followed him, and was slain there, after having laid waste and almost destroyed the country of the Picts. This was in 741 , and he is said to have been killed by a single man, who lay in wait in a wood 
at a ford. There is such a place on the east of Loch Ryan, at the border line between Carrick and Galloway, where there stands a large pillar stone known as Laight Alpin, or the grave of Alpin.

It has to be remembered that the succession to the Pictish throne was through females, and that up to this time no instance occurs of the son of a previous king succeeding. The fathers are frequently men of another race, one being a prince of the Saxon house of Northumbria, and another a Strathclyde Briton. The name of Angus MacFergus suggests that his father may have been a Scot, and if so, he may have had some claim to the throne of Dalriada. It is remarkable that the first occasion on which the son of a previous king comes to the throne is in the case of Talorgan, son of Angus, in 780, who followed three intervening kings, and this break in upon the law of Pictish succession may be the result of Scottish ideas.

It is also to be observed that the next instance is the case of the successor of the second Angus MacFergus in 834, who was the son of his brother and predecessor, Constantin MacFergus, and it seems 'probable that they belonged to the royal family of which the first Angus, son of Fergus, was the founder, and which appears to have been peculiarly connected with Fortrenn,' the frontier province of the Picts between the Forth and the Tay. Both Constantin and Angus are recorded as ruling in Dalriada.

In 765, in the period between the death of the first Angus and his brother Brude, sons of the first Fergus, and the accession of Constantin and the second Angus, sons of the second Fergus, the Scots seem to have risen in Dalriada, under Aedfin, son of Ecdach, who is called King of Dalriada in the Ulster Annals, and died in 778. The death of Fergus Mac-Echach (apparently his brother), King of Dalriada, is recorded in 781. In 832 there appears as a claimant for the Pictish throne, Alpin, King of the Scots, a Scot by paternal descent, but whose name, like 
that of the previous Alpin, shows that his mother was a Pict. The mediæval chroniclers call her Fergusia, daughter of Hung or Angus, King of the Picts. The Chronicle of Huntingdon records that 'in the year 834 [a mistake for 832, which Skene identifies as the true date], there was a conflict between the Scots and Picts at Easter, and many of the more noble of the Picts were slain, and Alpin, King of the Scots, remained victorious, but being elated with his success, he was, in another battle fought on the 20th of July in the same year, defeated and decapitated.' Pitelpie, formerly Pitalpin, near Dundee, is the traditional site of this battle, and Rathelpin, or the Fort of Alpin, near St. Andrews, 'seems,' says Skene, ' to indicate that it was in the province of Fife that he found his support and established himself after his first success.' With this Alpin, the father of Kenneth, we touch definite historic ground, after an interval of ninety-one years from the death of the previous Alpin, the last established monarch of Dalriada in direct descent of the family of Aidan and Fergus.

The mediæval lists of the kings only recognise the later Alpin and have evidently confused the two. They give fairly correctly the early monarchs of the house of Fergus down to Domnall Breac. The names which follow are evidently taken partly from his descendants, partly from the house of Lorn, and partly from the Pictish rulers of Dalriada. Five years after his father's death appears Kenneth, the son of Alpin, of whom the Pictish chronicle says that he "first of the Scots governed Pictavia happily for 16 years. Two years, however, before he came to Pictavia he acquired the kingdom of Dalriada.' The Chronicle of Huntingdon says that" he "succeeded his father Alpin in his kingdom and that in the seventh year of his reign, which corresponds with the year 839, while the Danish pirates, having occupied the Pictish shores, had crushed the Picts, who were defending themselves, with a great slaughter, Kenneth passing into their remaining territories turned his 
arms against them and having slain many compelled them to take flight, and was the first King of the Scots who acquired the monarchy of the whole of Alban and ruled in it over the Scots.' In his twelfth year, it says, he 'encountered the Picts seven times in one day, and having destroyed many confirmed the kingdom to himself.' These dates correspond with a terrible defeat of the Picts by the Danes in 839 in which their king, his brother, and the Pictish ruler of Dalriada all fell, and with the date of the last Pictish King in the Pictish Chronicle, whose reign terminated in 844. It seems, therefore, clear that Kenneth inherited a kingdom from his father, and that it was not Dalriad,a, which he is recorded as conquering first. Unfortunately there is a blank in the Irish Annals of Tighernac between the years 765 and 973 , and there is also a hiatus in the Pictish chronicle, but from four of the later chronicles, Mr. Skene thinks the hiatus can be supplied, and the account they give contains the statement that the Scots inhabited Galloway along with the Picts, to which Giraldus Cambrensis adds 'they effected an extension of their territories,' and the Scala Chronica adds 'as also Argyll and the Isles.' It proceeds to give the traditionary account of the conquest of the Picts.

We have seen that Eochaidh Buidhe had passed from Dalriada to rule in Galloway, and that there his descendant, the first Alpin, after conquering the country, had met his death. It seems, therefore, probable that the kingdom of the second Alpin to which Kenneth succeeded was Galloway. Galloway at an early period included Carrick, into which there seems to have been a considerable Scottish immigration from Kintyre, and Gaelic was spoken in Carrick in Queen Mary's time, and in Pictish Galloway so late as the seventeenth and even the eighteenth century. The question then comes, what was the later Alpin's connection with the original royal house of Dalriada. That he was a descendant is the unvarying testimony of all the narratives, but there is obscurity as to the precise links. After Fergus, 
the first king, there had ruled, second, Domangart ; third, his son, Comgall ; and fourth, Comgall's son, Conall, who received St. Columba ; fourth, Gabran, brother of Comgall ; and sixth, Aidan, son of Gabran; and seventh Eochaidh Buidhe, son of Aidan.

Mr. Skene points out that St. Berchan in his so-called prophecy (of the twelfth century), after a few stanzas which refer to Conall, son of Comgall, passes at once to the reign of Kenneth Macalpin with these words :-

\footnotetext{
'A son of the clan of his son will possess

The kingdom of Albany by virtue of his strength.'
}

Conall had seven sons. The Tract on the Men of Alban, which gives a detailed account of the descendants of Fergus Mor for some generations, gives another notice, and says that from Eochaidh Buidhe, son of Aidan, there branched off two clans, "the clan Fergusa Gall, son of Eachach Buidhe or the Gabranaigh, and the clan Conall Cerr, son of Eachach Buidhe, who are the men of Fife in the Sovereignty, that is the clan of Kenneth, son of Alpin, son of Aidan.' Conall Cerr succeeded his father as King of Dalriada, and was killed fighting against him and his Galloway Picts in Ireland in 629. We have seen that the existence of a Rathelpin in Fife indicates that Alpin had a special foothold in that province, and in 807, a Conall, son of Aidan, killed Conall, son of Tadg, the Pictish governor in Kintyre. It may therefore be the case that Alpin, father of Kenneth, and son of Aidan, was descended from Conall Cerr, son of Eachach Buidhe, and Mr. Skene suggests that the line of succession may have reverted from the descendants of Domnall Breac to those of Conall Cerr, his brother and predecessor, among whom may have been the Aed finn, recorded as King of Dalriada in 778. On the other hand the genealogy in the Tract of the Men of Alban gives a connected line thus : 'Kenneth, son of Alpin, son of Eachach, son of Aeda find, son of Eachach, son of Domangart, son of Domnall Breac,' deducing the later Alpin from a son of Domnall Breac, 
called Domangart. The mediæval chroniclers make their Alpin the son of Achaius (the Latinised form of Eocha), who is treated as a great potentate who made the league with Charlemagne and added the tressure flory counter flory to the Scottish Royal Arms, and call this Achaius, the son of Ethfin or Aed finn. The discrepancy between St. Berchan and the Tract on the Men of Alban is accounted for by the existence of the two Conalls.

Kenneth Macalpin was succeeded by his brother Donald, and the Pictish Chronicle contains the significant statement that in his time the Gael established with their king in Forteviot the rights and laws of the kingdom of Edus, son of Ecdach, Edus being the Aedfin who made the stand in Dalriada against the Picts. It is clear that he was a ruler who had largely influenced the institutions of his race and was remembered with respect It appears to me that the pedigrees given in the Irish Tract on the Men of Alban (before 1372), and the early Latin Chronicles of 1165, 1187 and 1251, deserve careful consideration, the distinction being always kept in view between the value of these chronicles as lists of monarchs supposed to have ruled over the whole of Dalriada, and their value when they record direct descent. For this purpose the kings whose descendants either died out or did not succeed, the kinglets of the house of Lorn, the Pictish rulers introduced in some lists and the statement as to the later Alpin being killed in Galloway, may be left out of view. This being done it is found that all these chroniclers give a direct descent of Kenneth Macalpin from father to son, as follows :-

Fergus.

Domangart.

Gabran.

Aidan.

Eochaidh Buidhe, d. 629.

Donald Breac, whose death is variously recorded in 642 and 686.

Domangart (killed in 673). 
Eachach, described as Eachach of the bent nose (habens curvum nasum), rineamhail, ronnauel, monanle, son of Domangart, son of Domnall Breac (c. 733).

Aeda find or Ed-albus, son of Eachach curvi nasi, whose death as rex Dalriata is recorded in 778.

Eachach, or Eochal venenosus filius Edalbi, or Eocha anuine or Angbhaidh.

Alpin, son of Eochal venenosi.

Kenneth Macalpin.

With this the genealogy of William the Lyon of 1185, the Scala Chronica, and the Norman chronicle of the Picts and Scots of 1317 all correspond, the simplest form being the direct genealogy in the Irish Tract on the Men of Alban.

With the omission of one link, the name of the second. Domangart, who never ruled, the same descent is given by Major as recited by 'the wild Scot hoary with age,' who appeared at the coronation of Alexander IIr., the names, running backward, being: 'Kenneth filius Alpini f. Ethachi, f. Ethafind, f. Echdachi, f. Donaldi Brek, f. Occabuid, f. Edain, f. Gobrann, f. Dovengard, f. Fergusii Magni, f. Erth, f. Eachach Munremoire.'

Some versions introduce another Eachach or Echadach, son of Eachach of the bent nose, as the father of Aeda-find, and the Annals of Tighernac record the death in 733 of Eochach MacEchach Ri Dalriada, while the Annals of Ulster record the death in 697 of 'Euchu nepos Domhaill,' grandson of Donald. It seems, therefore, certain that there were two Eachachs at this time, that the earlier, who only reigned for one year, was the son of Domangart, and that his son was the Eachach, the father (or brother) of Aeda find.

If the genealogy is correct-and as it is undoubtedly correct down to Domnall Breac, it appears to me that it is probably also correct as to the later generations more likely to be remembered-it completely answers the question to which branch of the Cinel Gabran did Kenneth belong, and the only remaining question is whether there are a sufficient 
number of generations between Donald Breac and Kenneth. If the version which gives ten generations is correct Eochaidh of the bent nose had three sons, the Eochaidh recorded as succeeding him, who died in 733; Alpin who was killed in Galloway in 741 and Aedfin who is credited with a reign of thirty years, and who died as king of a portion of Dalriada in 788. If the true number of generations is eleven, the second Eocha was the father and not the brother of Aeda-find. The younger Alpin might well have a claim on the elder Alpin's conquest of Galloway, and the mention of his grandfather as rex Dalriadi suggests that at that time he ruled in the original territory of the Cinel Gabran in Kintyre, from which communication with Galloway was easy. The distinct statement of Wyntoun ought not to be overlooked :-

\footnotetext{
' An fra this Fergus doun be lyne

Descendand even was be lyne, Kennath yat was aught hundred yere

And thre and fourtie passit cleir,

Eftir the blessed Nativitie

Or regnand he begouth to be

Fra the Peyhtis was put out.

The tend man without doubt

Was Kenaught Mack alpyne

Fra this Fergus even be lyne.'
}

Excluding Fergus, who died in 503, and Kenneth Macalpin, whose father was killed in 834, we have at least ten generations in 330 years. Applying an example from my own family as a test, I find that in a period of almost exactly 200 years (1705-1904), there were five generations, from the death of one ancestor to that of another. If the account which gives Donald Breac's date of death as 686 be correct, the first five generations of the ten covered a period of 183 years, and the second five a period of 148 years. If 642 be taken as the proper date, and this seems to be correct, the first five generations occupied 139 years, and the second five 192. The ten generations give an average of 33 years, the five I have used as an illustration 
one of 40 years, the later date assigned to Donald Breac's death one of 36 for the first five and 29 for the second five, and the earlier date one of nearly 28 for the first five, and of a little over 38 for the second five. If the real number of generations was eleven, the average for each is 30 years, and the average for the six who succeeded Donald Breac after 642 is 32 . There is, therefore, no impossibility in reconciling the number of generations with the period occupied, and it does not appear to me that either the vague statement of St. Berchan, or the inserted mysterious passage, apparently from an older version, in the Tract on the Men of Alban, as to 'the Men of Fife in the sovereignty i.e., the clan of Alpin, son of Aidan,' there being no record of any Aidan as the father of Alpin, and the Prophecy and the Tract, being contradictory of each other, is sufficient to displace the direct pedigree given in the same Tract. It is possible that the expression 'son of Aidan' may refer either to Aeda find his grandfather, or to his ancestor King Aidan, the greatest of the Dalriadic kings, and it will be seen that there are traces of carelessness and mistake in the passage in the Tract on the Men of Alban, on which Mr. Skene's argument is founded. As other words have obviously been slipped in in the wrong places, it is quite possible that the words 'son of Eochaidh' have been left out between 'Alpin' and 'son of Aidan.' The result is that there is no sufficient ground to discredit the direct pedigrees given by the earlier medirval chroniclers, for the period between Fergus and Kenneth as records of actual descent, that for the earlier portion of that period. they are fully corroborated, and that for the later portion there are adminicles of evidence in sources beyond suspicion, which are consistent with, and indeed support, the pedigree.

\section{II}

Of the character of the conquest by Kenneth Macalpin, it seems clear that it was rather a dynastic triumph than 
a racial subversion. The mediæval chroniclers embellish it with romantic episodes, such as the device employed by Kenneth to rouse the faltering spirits of the Scottish chiefs by the apparition of a man clothed in a robe covered with fish scales to represent a heavenly messenger, and the invitation of the great lords of the Picts to a banquet, where the seats were undermined, and those who occupied them slain easily in the hollow places into which they were precipitated when the supports were withdrawn. There are, however, historical facts sufficiently significant, whether these stories be artistic inventions, or traditions founded on real facts. One is the weakening of the Pictish power by the Danish invasions. Another is the extent to which the Pictish rule of succession had already been weakened by the descendants of Angus MacFergus. It only required the presence of a king strong enough, while having a good personal claim under the Pictish law, to alter it permanently in favour of his descendants, and even under Kenneth's successors there seems to have been one case in which the Pictish custom cast its weight into the scale. Most important of all were the facts that the two peoples were of kindred race and common language, and the influence of the Columban Church. The close connection of the Picts with the Angles of Northumbria had resulted in the supersession of the Columban rule by that of Rome, under Nectan MacDerili, the Pictish king, in 710, and the expulsion of the Columban clergy from the Pictish territories east of Drumalban in 717. The great Angus MacFergus had founded the monastery of St. Andrews before 747. The connection of his successors with Dalriada led, however, apparently to a reversion of friendliness to the Columban Church, and when the church of Iona had been plundered by the Norwegian pirates in 794, burnt by them in 802 , and the community of Iona slain by them in 806, Constantin Mac Fergus founded the church of Dunkeld, and the influence of the Columban Church again began to affect the regions of the southern Picts. The Pictish Chronicle records that 
in the seventh year of his reign over the Picts, i.e. 851, Kenneth Macalpin transferred the relics of St. Columba to a church which he had built, and Dunkeld became the head centre of the Scottish Church.

That there was any wholesale extermination of the Pictish population seems most improbable. One of the old legends of the earlier Pictish settlements says that the Picts conquered Alban from Cath to Forcu, but ' without destroying the people.' The Scottish conquest might well be expressed in the same terms. There is probably much truth in the traditions of dire misfortune overtaking the chiefs and nobles of the Picts. There would be forfeitures and replacements, and as time went on the higher positions and rights of property and overlordships would more and more pass into the hands of Scots connected with, or rendering good service to the royal house. The chief line of invasion and immigration would be from Dalriada, through Breadalbane, and down the Tay, the Earn, and the Pass of Leny, and a population of Scottish race would tend to increase and preponderate on these lines in Atholl, around Dunkeld, and in the vicinity of the capitals at Forteviot and Scone. Indeed, the true relation of the Scots to the other Celtic races seems to me to present a remarkable parallel to that of the Normans to the other Teutonic races. Not numerous in comparison with the others, they seem to have been the bravest warriors, and, exemplars of the highest type of religion in the ages of their supremacy. The notion which presents them as barbarian invaders, destroying a higher civilisation established among the Picts, seems quite untenable, and their superiority, and the introduction of their law of Succession, Church, and customs was in its day a development and advance, just as in a later age Queen Margaret's reforms, and the establishment of feudal charter rights, were an advance on their own. The one hundred and fifty men who, according to the Tract on the Men of Alban, crossed the Irish Channel with Fergus Mor, had developed under Aidan into a military

VOL. VI.

$\mathrm{X}$ 
kingdom, which carried its arms to the Forth and the Cheviots, and even, according to one entry, to the Orkneys. In spite of reverses and disasters, the race rallied to such an extent, that under Kenneth Macalpin it had established the centre of its kingdom on the banks of the Tay. He and one or two of his successors are still found recorded as Kings of the Picts, but in a generation or two the name of Pict is forgotten, the country north of the Forth as far as Moray is Scotia; and when the direct line of the royal race fails with Alexander III., four hundred years after King Kenneth's day, the repeated invasions of the Danes and Norsemen have left no permanent conquest, and Norman, Saxon, Pict, Briton, and Scot, from the Cheviots to the Pentland Firth, are welded into one whole as the Kingdom of Scotland.

The chief steps in that process may be briefly summarised. The succession followed the Gaelic rule of tanistry, giving preference to brothers over sons. Kenneth was succeeded by his brother Constantin (863), who fell in battle with the Danes in Fife in 877, and he by another brother Aedh, who was slain at Inverurie in the following year. Under Pictish law the succession then fell to Eocha, son of Run the King of the Strathclyde Britons, whose mother was a daughter of Kenneth Macalpin, and the Pictish party prevailed for the time, Eocha being placed on the throne while Ciricius or Grig, known to the mediæval historians as Gregory the Great, also of British descent, was associated with him. Both were driven out after eleven years, and Donald, son of Constantin, the heir by Scottish law, succeeded and reigned till 900, when he was killed by the Danes at Dunottar. He was succeeded by Constantin, son of Aedh (900 to 940), in whose time the old line of the British kings of Strathclyde failed, and the Britons elected Donald, Constantin's brother. Constantin, retiring in his old age to the Monastery of St. Andrews, was succeeded by Malcolm, son of his predecessor, Donald, who after having Cumbria or Strathclyde handed over to 
him by the Northumbrian Saxons, was killed by the men of the Mearns at Fetteresso in 954. Under his successor Indulph (954-962), Edinburgh was surrendered to the Scots. He was succeeded by Duff, slain at Forres in 967, and he by Cullen, who was slain by the Britons in 971. His successor, Kenneth, fortified the fords of Forth, 'gave Brechin to the Lord,' and was slain at Fettercairn in 995. His successor, Constantin MacCulindin, was slain two years after. Kenneth, the next king, fell in 1004 in ' a battle among the men of Alban themselves.' Malcolm, the next king, after defeating the Saxons at Carham in 1018, extended the frontier of Scotland to the Tweed, while the line of the British kings of Strathclyde, descended from the Scottish Donald, terminated in his time, and Strathclyde is henceforth found as a principality under the son of the Scottish monarch. He died in 1034, leaving no male issue, but his grandson by his daughter Bethoc, who had married Crinan the lay Abbot of Dunkeld, 'the gentle Duncan,' succeeded him. He was murdered by Macbeth, who held the kingdom in alliance with the Norsemen of Caithness who had overrun the northern provinces, for seventeen years (1040 to 1057). The short-lived career of Macbeth's relative 'Lulach the fool' does not break the historical record. Under Malcolm Canmore (1057-1095) the kingdom was further consolidated, and after the reign of Donald Bane, the last example of succession according to the law of tanistry (1093), Duncan (1093-4), Donald Bane again and Eadmund (1094 - 1097), Edgar (1097-1107), Alexander I. (1107-1124), reduced the rebellious province of Moray. David I. (1124-1153) was succeeded by his grandson, Malcolm (1153-1165), who finally subdued the recalcitrant provinces of Galloway and Moray, from the latter of which Fordoun, with probably some exaggeration, says he removed the native population ' and scattered them throughout the other districts of Scotland, both beyond the hills and on this side thereof so that not even a native of that land abode there, and he installed therein his own peaceful 
people.' William the Lyon (1166-1214) put down revolts in Galloway and Moray, and subdued the provinces of Ross and Caithness. His son Alexander II. (1214-1249) subdued Argyll, which had been practically independent under the house of Somerled, and his son Alexander III. (1249-1285) defeated the Norsemen at Largs and completed the consolidation of the kingdom by the annexation of the Western Isles. With his granddaughter, the Maid of Norway, who died in 1290 on the way from Norway to take possession of her kingdom, the direct line of the monarchy of the Scottish Celtic race terminated.

The three great branches of the Dalriad Scots were the Cinel Gabran, the Cinel Lorn and the Cinel Angus, to which is sometimes added the Cinel Comgall or the descendants of Comgall, the brother of Gabran. The Tract on the Men of Alban also indicates further subdivisions of these houses. Thus 'the three powerfuls' of the Cinel Lorn were the Cinel Fergusa Salach, the Cinel Cathbath, whose jugulatio is recorded in 701, and the Cinel Eachaidh, son of Muredach. In recording the descent of Kenneth Macalpin, two versions continue after the reference to his father Alpin: "Son of Eachach, son of Aeda find, son of Domangart; here branch off the Cinel Gabran and the Cinel Comgall; son of Domnall Breac son of Eachachbuidhe; here branch off the Clan Fergusa Gall, son of Eachach buidhe id est, the Gabranaig and the Clan Conall Cerr, son of Eachach buidhe id est, the men of Fife in the Sovereignty id est, the Clan of Kenneth, son of Alpin, son of Aedan; here branch off the Clan Eachach buidhe, the men of the halfshare of Conaing (of the half land), son of Aidan, son of Gabran, son of Domangart, son of Fergus Mor, son of Erc; here branch off the Cinel Lorn Mac Erc, the Cinel Angus, the Cinel Gabran and the Cinel Comgall.'

The first reference as to the branching off of the Cinel Gabran and the Cinel Comgall after the name of the later Domangart seems to be a repetition and clerical error, caused by the existence of the two Domangarts, for it was 
of course from the sons of the first Domangart that these houses came.

Thus in addition to the four great tribes, we have descendants of Eachach Buidhe, known as the Clan Fergusa Gall, and the Clan Conall Cerr who are described as the men of Fife, the Clan Eachach Buidhe and the men of the halfshare of Conaing. It seems possible that here we have indications of settlements either then or at a subsequent date in Fife and possibly in Galloway, where Eachach Buidhe reigned and where the Scottish name Ferguson is frequent, and the family of Craigdaroch on the borders of Galloway and Dumfriesshire, said to be the oldest in the south of Scotland, carry the lion rampant on their arms. The family of Kilkerran in Carrick, who carry different arms, similar to those borne by the same name in Atholl and Aberdeenshire, by tradition came from Atholl before the time of Robert the Bruce. The race of Conaing have been located in Kintyre.

The district of the Lennox was originally the British territory of Reged, and in the end of the tenth century the Scottish King of Scone, whose predecessors had been killed by the Britons, found it desirable to fortify the fords of Forth. By the twelfth century, however, it was occupied by a Gaelic population, ruled over by Earls, whose alleged Saxon descent, as given by the earlier peerage writers, seems erroneous, while their names correspond with the Celtic origin attributed to them in the Irish pedigrees. It is probable that the district was occupied by Scots, and curiously enough, it is found associated with one of the clans mentioned in the Tract on the Men of Alban, and the only one whose name corresponds to that of a modern clan. The Annals of Ulster record that in 1216, 'Trad O'Mailfabhail, chief of Cinel Fergusa, with his brothers and many others was slain by Muireadhach, son of the Mormaer of Lennox.' It must, however, be kept in view that, apart from the Scottish Fergusons from Ayr and Galloway who settled in Ulster at the Plantation and in Covenanting times, there was an old Irish Cinel 
Fergusa, descended from Fergus, son of Eoghan, son of Niall of the Nine Hostages. It is, however, unlikely that an Earl of Lennox would be fighting in Ireland so late as the year in which William the Lyon died.

The district of Atholl was the territory of the lay abbots of Dunkeld, and on the settlement of their line on the throne, in the person of Malcolm Canmore, the earldom was conferred on a branch of the Royal House, the first of whom was Melmare, brother of Malcolm III. The oldest clans of the district were the Fergusons, who always followed the Earls of Atholl, and were numerous there and in Balquhidder, who have been described as the oldest clan in the Highlands, and to whom tradition and the bards attribute descent from King Fergus, and the Robertsons, who are descended from and were apparently the male representatives of the old Celtic Earls of Atholl. Both of these clans may be safely set down as Scots proper, and of the race of Fergus.

How or when the family of Alpin acquired its connection with Fife, and to what extent Scots, as distinguished from Pictish Gaels, settled there it is impossible to tell, but undoubtedly the province was closely associated both with the house of Kenneth, and, after the defeat of Macbeth, with that of Malcolm Canmore, and its recognition as a bulwark of the Scottish monarchy is attested by the privileges conferred in 'the Law of Clan Macduff.' That the families of Arbuthnot and Spens were of Scottish, or, at least, Gaelic, descent to some extent is indicated by their claim to participate in these privileges, in virtue of their kinship to the Celtic Earls of Fife. The old Earls of Fife were admittedly of Celtic and probably Scottish descent, and the Strathbogie Earls of Atholl were a branch of their race.

Two of the greatest names in the borders suggest that the founders of these families were Scots who settled there after the conquest of Lothian. One is that of Scott, which speaks for itself as the designation given by a Saxon or 
British population to one of another race, and the other that of Kerr, which is a descriptive Gaelic denomination.

The extent of the Scottish element in Galloway is impossible to ascertain. The people were the last to retain the name of Picts, yet they had been for years in subjection to the Angles of Northumbria, and had been subsequently, at least so far as the coast districts were concerned, under the domination of the Norwegians. In the twelfth century it is found under the rule of native chiefs of Celtic descent, the first of whom is Fergus, Prince of Galloway, of whose birth and lineage no trace exists. Whether he was a Scot or a Pict it is impossible to say, but the Galloway over which he ruled included Carrick, where the Gaelic population was probably a Scottish one, superseding an older British one, and between which and the Galloway Picts, the feelings, even in comparatively modern times, were far from cordial. His name suggests that Fergus was of Scottish blood. The Kennedy Earls of Cassilis are descended from the old Celtic Earls of Carrick, themselves the progeny of Fergus of Galloway, through Roland of Carrick, who got a charter of the headship of the clan as 'Ken Kynol' from Earl Neil before 1256, and John Kennedy of Dunure, 'Captain of the Clan Muintircasduff' (the people of the blackfeet), about 1346.

The original territory of the Scots in Dalriada or Argyll and the adjacent islands had, in the period between the ninth and twelfth centuries, been swept and subdued by the Norsemen. With the weakening of their power, the native tribes arose, under Somerled, whose father's and grandfather's names are Gaelic, and the result was the founding of the great house of the Lords of the Isles, and the rise of the great clans of Macdonald and Macdougall. I see no reason to suppose that the race of Somerled were Picts rather than Scots, and indeed some pedigrees trace them to a younger son of Fergus, and the chief seat of their power was in Islay, which had been Scottish territory, while the physical characteristics attributed to them in an old Irish 
poem correspond with those that distinguished the Milesian stock.

The Irish genealogies of several of the Highland clans, which date from about the year 1400, and on which the MS. of 1467 in the Advocates' Library is based, indicate that the Highland clans fall into several classes. The older descent is mythical and obviously fabulous.

1. The Campbells and MacLeods are taken back to Fergus Leith Dearg, son of Nemedh, who is placed long before Picts and Scots appear in Ireland. But it may indicate that these clans were in Scotland before the Scots, and are therefore of Pictish descent, and the Campbells are found in the district of Mid-Argyll, which was not settled by the Dalriads.

2. The race of Somerled is traced to Colla Uais, son of Eochaid Doimlein, King of Ireland.

3. From the Hy Niall of Ireland are brought the Lamonds, Maclachlans, Clan Somairle, and MacEwen of Otter.

4. From Corc, son of Lughaidh, King of Munster, of the line of Heber, are said to be descended the Celtic Earls of Mar and Lennox.

The above have no connection with the family of Erc, although several of the clans mentioned inhabited Scottish Dalriada, and the last three groups are of Scottish race; but the remaining genealogies are all deduced from the Dalriadic tribe of Lorn, and may be classified thus :-

From Fearchar fada, son of Fearadach finn, who died in 697, and is given as descended from Muredach, son of Lorn Mor-The Clan Duff, the Macnaughtons, the Clan an Toshach, i.e., the Clan Gillachattan, and the Clan Cameron.

From Fearchar Abraruadh, son of Feradach-The MacLeans, the Colquhouns in Lennox, and the Clan Consithe in Fife.

From Donald Donn, son of Fearadach-The Clan Lauren (MacLarens), the Clan Aid or Ay. 
From Cormac, son of Aibertach, son of Feradach -(a) The clan Annrias (Rosses), the Clan Kenneth (Mackenzies), the Mathesons, and the Macduffies; (b) the MacNabs; (c) the Clan Gregor; (d) the Clan Quarry, the McKinnons, the Macmillans, and the MacLennans.

It is at once remarkable that these genealogies are all traced from the tribe of Lorn, and that several of them are genealogies of great clans in Moray, Ross and Inverness, far outside the bounds of Dalriada. It is still more remarkable that there is no trace of any descended from the elder sons of Lorn, or from the Cinel Gabran, the Cinel Comgall, or the Cinel Angus. Mr. Skene in his examination has pointed out that these genealogies are generally trustworthy up to about the date of Kenneth Macalpin, but that the connection with the Dalriadic Lorn Mor completely breaks down. 'They may,' he says, 'be regarded as trustworthy only in so far as they show the links of the descent of each clan from its eponymus as believed in the fourteenth and fifteenth centuries, and the grouping of certain clans together where a common ancestor within the historic period is assigned to them.' Probably the Aibertach, from whom several of the clans are deduced was an actual personage, at a later date than he is assigned to, for he is said to have had twelve tribes inhabiting the Norwegian territory, viz. Greagraid of the champions commonly called Mull, and Tiroda (Tiree), and Cruibhinis or Craobhinis (or Island of Bushes-Iona). It is probable that to some extent the clans whose genealogies are thus given, and who in historical times are found holding possessions in Lorn, in Breadalbane and Balquhidder, and in Lennox, were really descended, as believed, from the family of Lorn, and were at any rate of Scottish extraction. The same, however, cannot be predicated, though it may be true, of the Lochaber and Badenoch clans, and it becomes more improbable in those of Moray and Ross. ${ }^{1}$

1 There is a passage in M'Firbis's Book of Genealogies which ought also to be kept in view, of which he says, 'This account I found among the books of Fardeorough 
It appears to me that the conclusion arrived at by Skene is irresistible, that the mass of the population of the Highlands north of Argyll and possibly Atholl, were the descendants of the old Pictish tribes, who formed the northern or Caledonian Picts. At the same time much happens in a few centuries, and some of the most famous Highland clans, such as the Frasers, Menzies, and Stuarts were of Norman, or as the Murrays and Sutherlands of alleged Flemish descent, though it is more probable that the original Freskin was a Gael of Moray. The comparatively brief period in which a clan could rise is illustrated by the history of the Farquharsons. Scots as well as Normans may have accompanied the monarch in the assertion of his power benorth the Mounth, and Scots were in the field two hundred years before Malcolm Canmore's Saxons, and another half-century before King David I.'s Normans. It is quite possible that individuals penetrated to the north and founded successful families, and that however erroneous the details of the descent may be, where links are obviously wanting, there is some basis of fact for the tradition.

It cannot be assumed that the Mormaers of the great Pictish provinces, whose names are recorded in historic times, were themselves Picts. Indeed the statement in the Book of Deer, which says that when Columba came there 'Bede the Pict' was Mormaer of Buchan, may suggest that his later successors at least were Scots. In the case of Angus there is the tradition that King Kenneth was killed in 995, by Finella, in revenge for the death of her son, killed by him at Dunsinnan, Finella being the daughter M'Firbis, who was a Sennachaidhe well acquainted in Alban and much frequented it' :-

'The Clan Domnall, Clann Ragnall, Clann Alasdair, Clan Tsithig (Sheehy), Clann Eachan, Clan Eadhain, Clann Dubgall, and Clann Ragnall Mhic Domnall Ghlais are of the race of Eremon.

'Mac Gille-Eoin or Mac Gille a Ea-in (MacLean), the two MacLeods (Harris and Lewis), Mac Cennigh (Mackenzie), Mac-a-Toisigh (Mackintosh), Murmor Hundon (Mormaire of Moray ?) are of the race of Conaire.

' Murmor Abhail (Mormaer of Atholl), Murmor Mair (Mormaer of Mar), Murmor Gall (Mormaer of Galloway), Mac Cennedig (Kennedys), Muirgeach Og, Lord of Granta (Grants), Mac Cregan (Macgregors?) are also of the race of Eremon.' 
of Conquhar, Mormaer of Angus, and the probability being that the later Celtic Mormaers of Angus were Scots. In the Irish MS. the line of the historic Mormaers of Moray, including both Macbeth and Lulach, Kings of Scotland, is given in the genealogy of the Clan Duff as among the descendants of Lorn Mor. It is most probable that just as these dignities passed later to Normans either by marriage or grant, so between the Scottish conquest and the Norman immigration they passed from Picts to Scots.

The traditions of one group of clans deserve special consideration as they assert a descent from the Scottish Royal House. The proud motto of the Macgregors is 'Is rioghail mo dhream,' ' Royal is my race,' and they and the connected clans known as Clan Alpin claim descent from Kenneth Macalpin. The siol Alpin includes the clan Gregor, the Grants, the Mackinnons, Macquarries, Macnabs and Macaulays. Bonds of Manrent exist between the Macgregors and the Mackinnons, the Mackinnons and the Macnabs, and the Macgregors and the Macaulays, in all of which relationship is affirmed, and an early connection between the Grants and Macgregors is undoubted. The Irish genealogies indicate that the group of clans to which the Macgregors and others of the siol Alpin are assigned, belonged to the great tribe of Ross, and in any case descent from Kenneth Macalpin is inconsistent with descent from Lorn Mor. The earliest possessions of the Macgregors were in Glenorchy, and the Macnabs in Glendochart, but it may be that when Alexander II. reduced Argyll, in which he was powerfully aided by the Earl of Ross, he planted the ancestors of these clans there. A similar explanation may be given for the settlement of the Macnaughtons, a branch of Clan Chattan, on Loch Awe and Loch Fyne, or it may be that the Clan Chattan, being the chief branch of the great tribe of Moray, they were brought by Malcolm, when he expatriated the men of Moray, placed them in new lands on both sides of the mountains, and replaced them with ' his own peaceful people.' 
It is indeed remarkable how many of the great nobles of Scotland at the time of Robert the Bruce, including Mar, Fife, and Atholl, Lennox and Strathearn, were of direct male Scottish descent, while the Bruces, Comyns, Umphravilles, and probably the Campbells owed their great possessions not so much to direct grant as to a Scottish ancestress. It is impossible to determine whether the race of Douglas was of Scottish or Norman extraction, and it seems at least probable that the clan and name of Forbes, whose chief holds the premier barony of Scotland were also Scots, and that there is something in the tradition which connects them with the Urquharts and Mackays. Two traditions, supported by the name Ochoncar, derive the Fubeses from Ireland, and there was in Ireland a Clan MacFirbis.

The result of the investigation is, that the Scottish element which gave its name to the country was a large and important one in the composition of its population and the formation of its character. The military system of the Celtic period continued to provide a large portion of the Scottish armies throughout the whole independent history of the realm. Recognised as 'Scottish service,' it existed side by side with ' knight service,' it is shown to be in full vigour early in the eighteenth century in Atholl by the lists, printed in the Chronicles of Atholl and Tullibardine; and it was under the old obligation of Feacht and Sluaged, hosting and expedition, that the clans rose under Montrose and Dundee and marched to Derby with Prince Charles. There can be little doubt that after the conquest by Kenneth Macalpin, which has considerable resemblance to that of England by William the Norman, Scots would be largely settled among the Picts, and would be specially numerous in the central region watered by the Tay and the Earn. There can be as little doubt that many of the families who assumed territorial designations as their surnames, when these came into vogue, were Scots, and that the Ogtierns, who were the smaller landowners, continued to exist side by side 
with Norman families as lesser barons, or 'gudemen' and proprietors holding of subject superiors, obtaining written charters, and assuming surnames, when these came into vogue, from their ancestral lands. For example, the Earls of Airlie and Clan Ogilvy are descended from a younger son of the old Celtic Earls of Angus, who obtained the feudal fief, and took his designation from the lands of Ogilvie. The house of de Brechin were the direct descendants of an illegitimate son of David, Earl of Huntingdon and Garioch, David the Scot, brother of the Celtic king. The House of Randolph, Earl of Moray, were sprung from a Dungal of Celtic name and race, whose possessions in Nithsdale were feudalised. Even the great family of Dunbar, Earls of March, though in the female line Saxons of Northumbria, were in the male line the progeny of a brother of the gentle Duncan.

The race of the lay abbots of Dunkeld, is still represented in male descent by the chief of the clan Donachie; and that of the lay abbots of Abernethy, whether it be Scot or Pict, in the female line by Lord Salton, whose ancestor inherited the title conferred on an Abernethy. It is probable that in many of the Highland clans the chiefs and 'duinewassails' were of Scottish descent. For more than two hundred and fifty years the Scots were truly the ruling race, and it was under their guidance that the country was changed from four independent and conflicting states into a compact kingdom with definite boundaries, which maintained its independence against a powerful neighbour for four hundred more, that Norman knights, and Saxon and Flemish merchants and tradesmen were welcomed as elements of strength in a greater national life, and that substantial advances were made in social progress and national development.

The Scots alone of the early races came to Scotland as a Christian people. The nobles of their race devoted themselves to the cause of its conversion, and they spread Christian civilisation not only through the Northern Picts, 
but far beyond its borders, among the Teutonic tribes who gave their name to England. They, among the Celts, as the Normans among the Teutons, had the highest ideal of organisation and of law, as well as the foremost military qualities, and with them, more easily and completely than with any other race, the Norman blood blended to form the guiding element of a strong, a logical, and an enduring national character. The perfervidum ingenium Scotorum in intellectual pursuits, the proud valour which inspired the French proverb, fier comme un Ecossais, are in no small degree due to the special Scottish strain in the blood of modern Scotsmen, and discarding all fabulous and mythical antiquity, we may yet affirm that no race has more cause to be proud of its far descended royal line, or has produced a representative whom it has more reason to revere than he of whom it was written, "There was not born of the Gaidhel a being more illustrious, or more wise, or of better family than Colum Cille. There came not of them any person who was more modest, more humble, or more lowly.'

\section{SOME UNRECORDED INCIDENTS OF THE JACOBITE RISINGS}

Alexander Carmichael

(Continued from vol. vi. p. 283)

Prince Charlie

Prince Charlie and his few followers landed in Eriskay from France on the 23rd of July 1745. Eriskay is a hilly, rocky, boggy, sandy, small island standing in the sound between Barra and Uist. There was only one isolated family there then: there are one hundred congested familiese now in Eriskay. The Prince and his followers slept two nights in Eriskay, sailing on the 25th July 1745 for Lochnan-Uamh, lying between Arasaig and Moideart.

Near where the French frigate anchored, a boat from 